\title{
Cultivation of strawberry in substrate: Productivity and fruit quality are affected by the cultivar origin and substrates
}

\section{Cultivo de morango em substrato: Produtividade e qualidade dos frutos são afetados pela origem da cultivar e substratos}

\author{
Maria Inês Diel', Marcos Vinícius Marques Pinheiro², Leonardo Antonio Thiesen², \\ Bruna Stringari Altíssimo², Ezequiel Holz², Denise Schmidt ${ }^{2 \star}$
}

${ }^{1}$ Universidade Federal de Santa Maria/UFSM, Departamento de Fitotecnia, Santa Maria, RS, Brasil

2Universidade Federal de Santa Maria/UFSM, Departamento de Ciências Agronômicas e Ambientais, Frederico Westphalen, RS, Brasil

${ }^{*}$ Corresponding author: denise@ufsm.br

Received in February 6, 2018 and approved in July 3, 2018

\begin{abstract}
The production and quality of strawberries may vary according to cultivar, transplant origin, and the system of plant cultivation. The objective was to evaluate the effect of different organic substrates and different transplant origins on strawberry production and fruit quality. The experiment was conducted in a randomized complete block design with a $2 \times 2 \times 4$ factorial scheme using two cultivars (Albion and Camarosa) obtained from different origins (National-Brazilian and Imported-Argentine) and four combinations of substrates: (crushed sugarcane bagasse [70\%] + organic compost [30\%], crushed sugarcane bagasse [70\%] + Carolina ${ }^{\circledR}$ commercial substrate [30\%], burnt rice husks [70\%] + organic compost [30\%], and burnt rice husks [70\%] + Carolina ${ }^{\circledR}$ commercial substrate [30\%]). The experimental unit was composed of eight plants, with repetition in four blocks. The quality parameters of titrable total acidity, total soluble solids, ratio of sugar / acidity, firmness, and pulp coloration (chroma, hue angle, and $L^{*}, a^{*}$ and $b^{*}$ ) were evaluated, as were the production parameters of total number of fruits, total fruit production, average fruit mass, non-commercial fruit production, commercial fruit production and total productivity. The substrate influences the strawberry production variables. Fruit yield was highest in the Camarosa cultivar grown on the S3 substrate mixture. The cultivar, the transplant origin and the cultivation substrate influence fruit AT. SST and AT / SST are influenced only by cultivar and transplant origin. Chroma differs between plants with different transplant origins. Camarosa of National origin cultivated in burnt rice husks + organic compost presented the best production results and fruit quality.
\end{abstract}

Index terms: Fragaria $x$ ananassa; cultivar management; protected cultivation.

\section{RESUMO}

A produção e a qualidade dos morangos podem variar de acordo com a cultivar, a origem das mudas e o sistema de cultivo das plantas. O objetivo deste trabalho foi avaliar o efeito de diferentes substratos orgânicos e diferentes origens de mudas na produção de morangos e na qualidade dos frutos. 0 experimento foi conduzido em blocos ao acaso, em esquema fatorial $2 \times 2 \times 4$, com duas cultivares (Albion e Camarosa, de dias neutros e dias curtos, respectivamente), duas origens de mudas (nacional-Brasileira e importada-Argentina) e quatro combinações de substratos: (Bagaço de cana-de-açúcar triturada [70\%] + Composto orgânico [30\%], Bagaço de cana-de-açúcar triturada [70\%] + substrato comercial Carolina ${ }^{\circledR}[30 \%]$, casca de arroz queimada [70\%] + composto orgânico [30\% ] e cascas de arroz queimadas [70\%] + substrato comercial Carolina ${ }^{\circledR}[30 \%]$ ). A unidade experimental foi composta por oito plantas, com repetição em quatro blocos. Foram avaliados parâmetros de qualidade: acidez total titulável, sólidos solúveis totais, proporção de açúcar/acidez, firmeza, coloração da polpa (chroma, ângulo de matiz e $L$ * $a$ * e b *), bem como parâmetros de produção: número total de frutas, produção total de frutas, massa média de frutas, produção de frutas não comerciais, produção comercial de frutas e produtividade total. A cultivar Camarosa de origem nacional, quando cultivada em cascas de arroz queimadas+composto orgânico, apresentou os melhores resultados de produção e qualidade dos frutos.

Termos para indexação: Fragaria x ananassa; manejo de cultivar; cultivo protegido.

\section{INTRODUCTION}

The largest strawberry (Fragaria $x$ ananassa) producers in the world are China, the United States of America, Spain and Japan (Faostat, 2017). Strawberry is an economically important crop because its fruits are widely consumed in natura (in unprocessed forms) and processed by a variety of industries (Xu et al., 2014); aside from its sweet taste and organoleptic properties, strawberry has been observed to aid in the treatment of chronic diseases

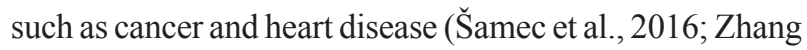
et al., 2008). In addition to flavour, which is determined by the content of acids and soluble solids (Krüger et al., 2012), the acceptance of fruits by consumers depends on the colour and firmness of fruits. The market generally favours 
fruits with a good appearance, flavour and durability and a balance between physical and chemical characteristics and a high antioxidant content (Šamec et al., 2016). These properties can be modified and can depend upon systems of production and techniques for controlling environmental factors (e.g., cultivation in a protected environment) (Krüger et al., 2012).

The cultivation of strawberries in semi-hydroponic systems has been growing annually. In these systems, the use of substrates with ideal physical characteristics for the development of the plants is important; an ideal substrate should, for example, provide mechanical support for the roots, a balanced and stable porosity in order to provide sufficient air and water for root metabolic processes, and a good water retention capacity in order to avoid stress due to water deficit or hypoxia (Abad et al., 2005).

The choice of cultivar and transplants is also important for obtaining good crop yields. In the state of Rio Grande do Sul, there are regions approximately $900 \mathrm{~m}$ above sea level with low summer temperatures, which would provide suitable climatic conditions for the production of strawberry transplants (Wrege et al., 2007). When strawberry transplants are started in cooler locations, they can achieve relatively higher rates of productivity and fruit quality than can transplants started in warmer locations; the environment where a transplant was produced has a direct influence on cultivation and final production (Cocco et al., 2015).

The cultivar and the origin of the transplants are determining factors for the overall success of strawberry cultivars because these factors can contribute to the quality of the fruit. Additionally, good genetic characteristics and the sanitary procedures associated with semi-hydroponic cultivation can reduce the phytosanitary risks to which the plants are exposed (Antunes; Duarte Filho, 2005).

Systems for the cultivation of strawberries still require much study. For example, a great number of possible substrates exist, and the environment can affect yields and fruit quality as previously discussed. In this context, the objective of the present study was to evaluate the production and the quality of two strawberry cultivars obtained from different origins and grown in different organic substrates.

\section{MATERIAL AND METHODS}

\section{Conditions for cultivation and preparation of the study area}

The experiment was carried out at the Federal University of Santa Maria, Campus of Frederico
Westphalen, at the geographic coordinates $27^{\circ} 23^{\prime} \mathrm{S}$, $53^{\circ} 25^{\prime} \mathrm{W}$, at $493 \mathrm{~m}$ above sea level. The climate of the region, according to the Köeppen classification, is Cfa, humid subtropical, and presents the characteristics of a rainy temperate climate with an average annual precipitation of $1800 \mathrm{~mm}$ distributed throughout the year (Alvares et al., 2013). The experiment was conducted in a semi-hydroponic system in an arched, galvanized steel greenhouse measuring $20 \mathrm{~m}$ long by $10 \mathrm{~m}$ wide and 3.5 $\mathrm{m}$ in height and was arranged in a north-south direction. The strawberry transplants were transplanted into white tubular bags with a mesh diameter of 150 microns; the bags were then placed on wooden benches elevated 0.8 $\mathrm{m}$ above the soil.

Irrigation was carried out by means of a drip system located inside the substrate bags and composed of dripping tubes spaced $0.10 \mathrm{~m}$ apart. Fertigation was carried out according to a formula developed by Gonçalves et al (2016) and applied at a frequency in accordance with crop requirements.

\section{Experimental design}

The experiment was conducted under a randomized block design in a $2 \times 2 \times 4$ factorial arrangement with two cultivars (Albion and Camarosa, with neutral and short days, respectively), two transplant origins (National and Imported) and four combinations of substrates (S1: crushed sugarcane bagasse [70\%] + organic compost $[30 \%]$, S2: crushed sugarcane bagasse $[70 \%]+$ Carolina $^{\circledR}$ commercial substrate [30\%], S3: burnt rice husks [70\%] + organic compost [30\%], and S4: burnt rice husks [70\%] + Carolina $^{\circledR}$ commercial substrate $[30 \%]$ ) for a total of 16 treatments distributed in four blocks and an individual experimental unit composed of eight plants, totalling 32 plants per treatment.

Prior to planting, the substrate was washed until it reached an electrical conductivity of less than $1 \mathrm{mS}$ / $\mathrm{cm}$ to make it chemically inert. The National transplants were acquired from a nursery located in Agudo (Rio Grande do Sul, Brasil, between the Central Depression and the Middle Plateau) with the geographic coordinates $29^{\circ} 62^{\prime} \mathrm{S}, 53^{\circ} 22^{\prime} \mathrm{W}$ and at $83 \mathrm{~m}$ above sea level. The Imported transplants from Argentina were produced in the nursery Patagonia Agrícola S.A., located in the municipality of El Maitén, with the geographical coordinates $42^{\circ} 3^{\prime} \mathrm{S}, 71^{\circ} 10^{\prime} \mathrm{W}$ and at $720 \mathrm{~m}$ above sea level. The cultivars Albion (National) and Camarosa (National and Imported) were transplanted on May 26, 2015. The Imported plants of cultivar Albion were transplanted on June 8, 2015. 


\section{Plant parameters}

The following plant parameters were evaluated: total number of fruits (NTF), total fruit production (PTF, $g$ plant $^{-1}$ ), mean fruit mass (MMF, g), non-commercial fruit production (PFNC), commercial fruit production (PFC, $g$ plant $\left.^{-1}\right)$, and total productivity $\left(\mathrm{PT}\right.$, ton $\left.\mathrm{ha}^{-1}\right)$. Strawberries were harvested twice a week during the stage of complete maturation, and commercial and non-commercial fruits were then separated.

Non-commercial fruits were either deformed or had a mass less than $6.0 \mathrm{~g}$. Fruit quality variables included total titratable acidity (AT); total soluble solids (SST); ratio of total soluble solids / acidity (SST / AT); firmness; and pulp coloration (chroma variables, hue angle and $\mathrm{L}^{*}$ ). Evaluations of fruit quality were carried out during the production cycle to eliminate characteristics that may have been due to a variable harvest season.

The determination of total titratable acidity (AT) was performed by titration with a standardized $\mathrm{NaOH}$ solution $\left(0.1 \mathrm{~mol} \mathrm{~L}^{-1}\right)$, and the determination of total soluble solids (SST) was made with a manual refractometer $( \pm 2 \%$ accuracy), with results reported in ${ }^{\circ}$ Brix. The ratio SST/ AT was calculated afterwards using the content of total soluble solids and titratable acidity.

The firmness was determined with a bench penetrometer with a $6.0 \mathrm{~mm}$ tip. Pulp colour was evaluated by chroma, hue angle and the values of $\mathrm{L}^{*}, \mathrm{a}^{*}$ and $\mathrm{b}^{*}$, which were determined with a colorimeter expressing the components $\mathrm{L}^{*}$ [from white $(+\mathrm{L})$ to black $(-\mathrm{L})$ on the $\mathrm{z}$-axis], $\mathrm{a}^{*}$ [from red $(+\mathrm{a})$ to green $(-\mathrm{a})$ on the $\mathrm{x}$-axis], $\mathrm{b}^{*}$ [from yellow $(+b)$ to blue $(-b)$ on the y-axis], and $\left(b^{*} /\right.$ $\left.a^{*}\right)$. The apparatus was calibrated for the $L^{*}, a^{*}, b^{*}$ system using the following equation: $\tan ^{-1}\left(\mathrm{~b}^{*} / \mathrm{a}^{*}\right)$. The apparatus was calibrated with the $\mathrm{L}^{*}, \mathrm{a}^{*}, \mathrm{~b}^{*}$ regime and a standard white ceramic plate.

The results were submitted to analysis of variance to determine the effect of the different substrates, cultivars, and origins; the means of the variables were compared by Tukey's test with a $5 \%$ probability of error using the statistical program SAS (SAS institute Inc., 2010).

\section{RESULTS AND DISCUSSION}

\section{Temperature in the greenhouse}

The minimum and maximum air temperature in the greenhouse from May 25 to December 23, 2015, were 0.6 and $47.8{ }^{\circ} \mathrm{C}$, respectively. The average temperature had peaks greater than $20-25^{\circ} \mathrm{C}$, but for most of the cycle, it remained between 20 and $25{ }^{\circ} \mathrm{C}$ (Figure 1A). With respect to photosynthetically active solar radiation, there were decreases in some periods during the experiment, specifically until September, after which the average value remained above $12 \mathrm{MJ} \mathrm{m}^{-2}$ (Figure 1B).

Solar radiation, photoperiod, temperature and water in the soil have a strong influence on strawberry productivity (Krüger et al., 2012; Li et al., 2010). For example, a $3.0{ }^{\circ} \mathrm{C}$ increase in mean air temperature may reduce the number of fruits per plant (Radin et al., 2011). Heide, Stavang and Sonsteby (2013) also report that both air temperature and photoperiod control various physiological processes, such as floral induction, because high temperatures can cause flower abortion and induce the emission of stolons (Sonsteby; Opstad; Heide, 2013).

Radiation is especially important for the production and quality of strawberry fruits (Xu et al., 2014). For example, plant growth occurs only when the amount of solar radiation received is greater than the trophic limit, which is approximately $8.4 \mathrm{MJ} \mathrm{m}^{-2} \mathrm{~d}^{-1}$ for most crops and is considered to be the level at which a plant produces the minimum amount of photoassimilates necessary for selfmaintenance (Tullio et al., 2013). In the present work, the average photosynthetically active radiation met the needs of the crop. High solar radiation makes the production and conversion of photoassimilates more efficient (MartinezFerri et al., 2016), which favours the production of fresh fruit matter (Rosa et al., 2013); dry matter in the crown, roots, leaves and stolons; and the accumulation of reserve substances (Verdial et al., 2009) and of sugars in the fruit.

\section{Analysis of variance between the factors studied in each variable}

Regarding production, it was possible to observe significant interactions between the cultivar $\mathrm{x}$ origin of the transplants and, separately, for substrate combinations. For the fruit quality analyses, there was a significant threeway interaction (cultivars $\mathrm{x}$ origins of the transplants $\mathrm{x}$ substrates) for the variable AT, and for the SST/AT ratio, there was an interaction only between cultivars $\mathrm{x}$ transplant origins.

\section{Effects of cultivar, origin of the transplants and substrate combinations in on yield of strawberry fruits}

For total number of fruits (NTF), it was possible to observe that, for both Imported and National sources, the cultivar Camarosa showed significantly greater values than did the Albion cultivar. When comparing the origin of the transplants within each cultivar, there was no significant difference (Figure 2A). 

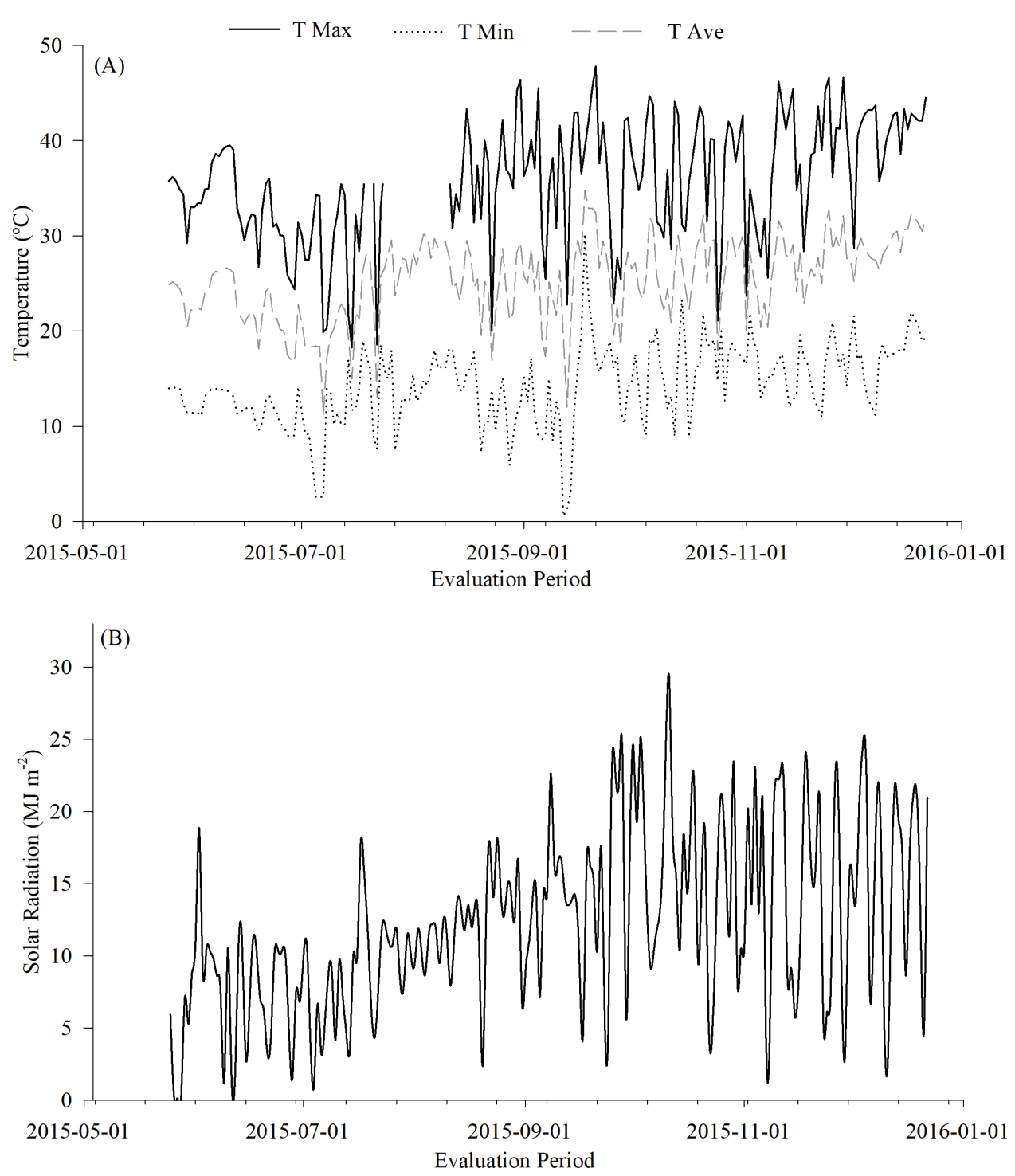

Figure 1: Maximum temperature (T Max), minimum temperature ( $T$ Min) and average temperature (T Ave) air temperatures (A) and solar radiation (B) recorded inside the greenhouse from May 2015 to December 2015.

The NTF values found in this work were higher than those found by Radin et al. (2011) for the cultivar Camarosa, which presented an average of 18 fruits per plant. According to Padua et al. (2015), the cultivar Camarosa produces approximately 17 fruits per plant, and Albion produces 12 fruits per plant. This can be attributed to the greater number of leaves in the Camarosa cultivar (Diel et al., 2017) conferring a greater net transformation rate of photosynthetic energy into fruit production.

For the total fruit production (PTF), commercial fruit production (PFC) and total productivity (PT) variables, it was possible to observe that, for the plants of National origin, the values for the cultivar Camarosa were significantly higher than those for Albion, but no significant difference was observed for the Imported plants. When comparing the origin of the transplants for the cultivars, the values for Camarosa of National origin were significantly higher than those for Camarosa of Imported origin. It was also possible to observe that, regarding the origin of the transplants, the Albion cultivar presented no significant differences for these variables (Figure 2B, 2C and 2D). 


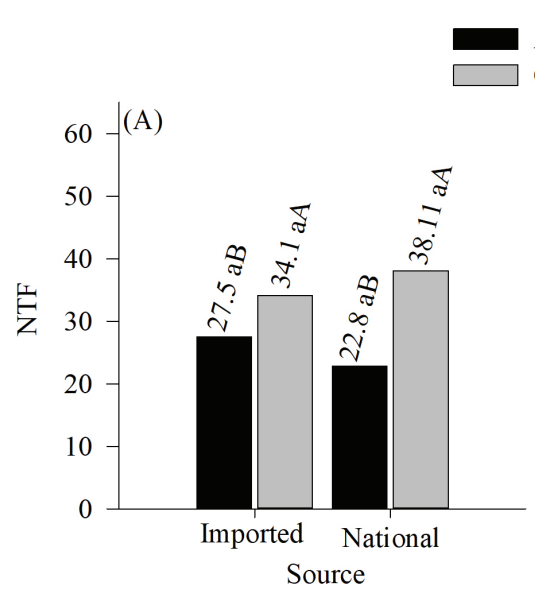

Albion

Camarosa

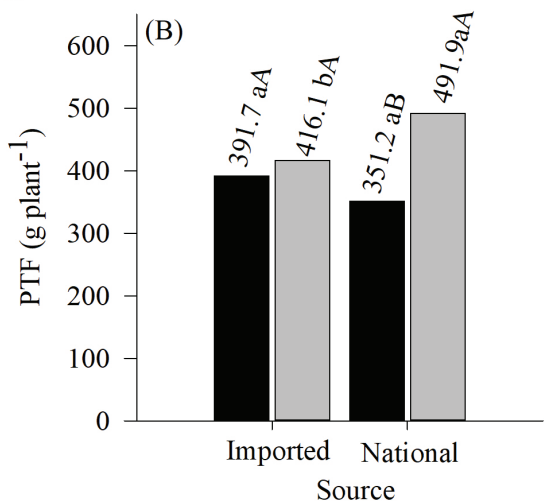

Albion Camarosa
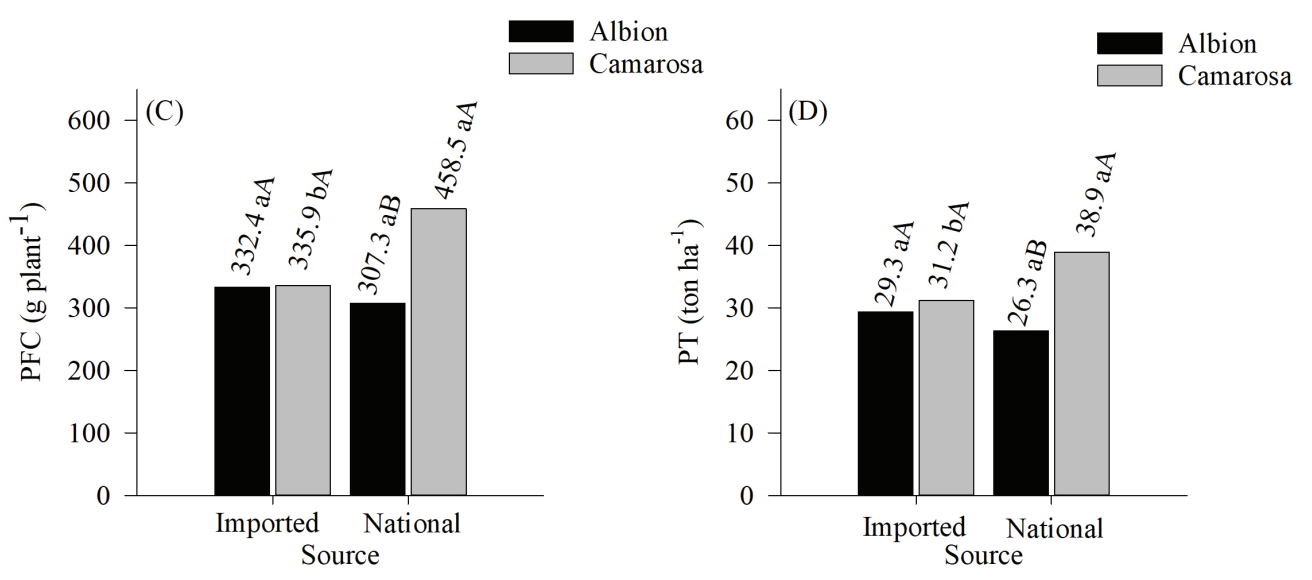

Cultivars

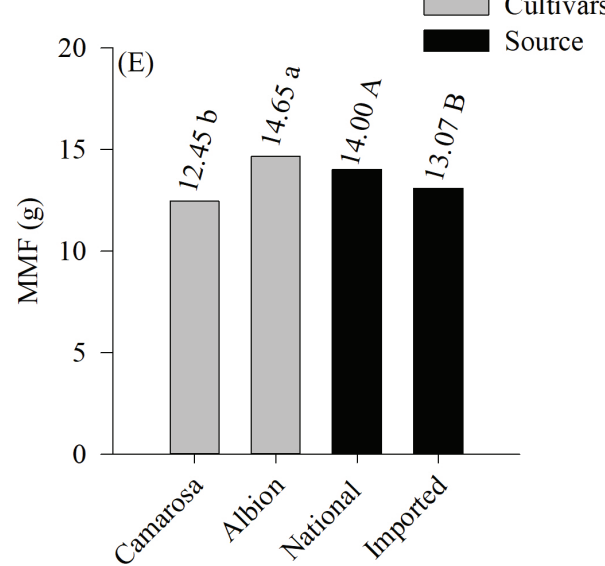

Cultivars / Source

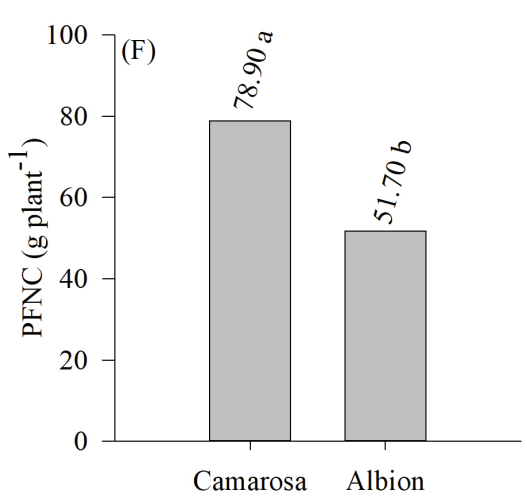

Cultivars

Figure 2: Production of strawberry cultivars of Imported and National origins grown in different substrates: (A) Total number of fruits (NTF); (B) Total fruit production (PTF); (C) Commercial fruit production (PFC); (D) Total productivity; (E) Average fruit mass (MMF); and (F) Production of non-commercial fruits (PFNC). Lowercase letters denote differences between the origins of the transplants within each cultivar, and capital letters denote differences between the cultivars for each origin based on Tukey's test $(p<0.05)$. 
The PTF results were opposite to what was verified by Oliveira and Scivittaro (2009), who found that Imported transplants from Chile performed better when compared to those produced in southern Rio Grande do Sul. Medeiros, Strassburger and Antunes (2008) observed that the cultivar Camarosa had a PTF of $345 \mathrm{~g} \mathrm{plant}^{-1}$, and Pádua et al. (2015) observed 157.34 and 137 g plant $^{-1}$ for Camarosa and Albion, respectively. Greater production was obtained by Godoi et al. (2009), with a total of 934.7 g plant $^{-1}$ in bags and closed systems. In this work, the commercial fruit yields were higher than those found by Pádua et al. (2015), in which values of 81.78 and $81.24 \mathrm{~g} \mathrm{plant}^{-1}$ were measured for Camarosa and Albion, respectively.

The responses of the production variables can be explained by the meteorological conditions and genetic backgrounds. The action of these two factors can act directly on the production of strawberry fruits (Rosa et al., 2013). For example, air temperature and photoperiod affect the fruiting of strawberry cultivars (Darnell et al., 2003) because they alter the beginning of flowering and delay the emission of new flowers (Bradford; Hancock; Warner, 2010) or even lead to flower abortion, making these environmental factors critical for maintaining flowering for a long period of time (Massa et al., 2015). For example, in neutral-day cultivars, flowering occurs under certain day and night temperature regimes (Massa et al., 2015), with the flowering stage persisting if the air temperature is approximately $21^{\circ} \mathrm{C}$ and ceasing at temperatures above $30^{\circ} \mathrm{C}$ (Durner et al., 1984). In the present study, there were periods with high temperatures above $40^{\circ} \mathrm{C}$, which may have reduced productivity.

Fruit production may also be affected by the vigour of the plants during the productive period. If a plant has a small leaf area, then the production of the fruits will be reduced due to the reduced production of photoassimilates. Such a pattern would demonstrate that plant nutrition as well as meteorological elements and irrigation are vitally important for crop production (Martinez-Ferri et al., 2016), and a lack of one factor may have a negative effect on the production of commercial and non-commercial fruits.

For the variable average mass of fruits (MMF), Albion had significantly higher values than did Camarosa. In addition, the Imported cultivars presented MMF values that were higher than those of cultivars of domestic origin (National) (Figure 2E). The Camarosa cultivar presented lower values than did Albion (Figure 2F). Imported transplants generally have a greater accumulation of cold hours; however, this may result in difficulties in the return to growth and lead to lower productivity, lower fruit quality and lower resistance to pests and diseases due to the stress caused by a long transport period (Morrison; Herrington,
2002). The fruits, if smaller than $6.0 \mathrm{~g}$, are classified as noncommercial. In the present study, high production of noncommercial fruits (PFNC) was observed for both Camarosa and Albion (9.2 and $11.3 \mathrm{~g} \mathrm{plant}^{-1}$, respectively). Pádua et al. (2015) observed lower masses of non-commercial fruits than did the present study $\left(6\right.$ g plant $\left.^{-1}\right)$, and Antunes; Duarte Filho, (2005) observed averages of $20 \mathrm{~g} \mathrm{plant}^{-1}$. Oliveira and Scivittaro (2009) observed heavier fruits in plants of Imported origin than in those of National origin.

It was observed that $\mathrm{S} 3$ (burnt rice husks $[70 \%]+$ organic compound $[30 \%]$ ) caused a significantly greater number of fruits (NTF), total fruit production (PTF) and total productivity (PT) than did the other substrates (Figure 3A, 3B and 3C). For commercial fruit mass (MFC), the S3 substrate only differed from the S4 substrate (burnt rice husk [70\%]

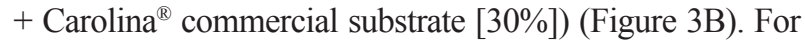
the mass of fruits (MMF), S3 differed from S2 (Figure 3D).

Substrates S1, S2 and S4 have relatively low densities and higher porosity, which led to low water retention capacity and may have negatively influenced plant growth and development. In contrast, the higher water and nutrient retention capacity in the fertigation probably promoted a greater fruit yield for this substrate treatment (S3) (Figure 4).

The results concerning the effect of the substrate are related to the physical characteristics of the substrate, as the water saturation content of a substrate can often be higher than $50 \%$; however, it can rapidly decrease to less than $10 \%$ in the case of a small increase of between $20-40 \mathrm{~cm}$ in the water tension of the water column (Wang et al., 2016). The low rates of productivity obtained for the combinations $\mathrm{S} 1$ and S2 can be attributed to the use of sugarcane bagasse in the composition of the mixture; for this combination, the lowest amount of water was available for the plants, leading to a greater water deficit. In contrast, the mixture of burnt rice husks and organic compost can provide better water use efficiency and productivity in the semi-hydroponic cultivation of strawberries (Diel et al., 2016).

The production of strawberries requires large amounts of water, especially for cultivation in protected environments, which depend entirely on water supplied through irrigation. Water consumption can differ substantially between cultivars due to a plant's total biomass and the efficiency of transpiration (Martinez-Ferri et al., 2016). In this way, the use of cultivars more tolerant to water deficit can provide better water use efficiencies (Martinez-Ferri et al., 2016). Camarosa stands out as being more efficient in its water use and generally has a longer phyllochron than does Albion, which reflects the higher rate of fruit productivity of Camarosa (Diel et al., 2016; Diel et al., 2017). 
Effects of cultivar, origin of the transplants and substrate combinations in on quality of strawberry fruits

The content of total soluble solids characterizes the sweetness in fruits (Silva; Dias; Pacheco, 2015) and, together with the titratable acidity, defines the strawberry aroma; both are directly influenced by genetic factors and environmental conditions (Cao et al., 2015). The flavour of a fruit is mainly determined by its total acid and total soluble solids contents and the relationship between these factors (Krüger et al., 2012).

The lowest averages of titratable acidity (AT) were observed in S4 for the Imported Camarosa cultivar and National Albion cultivar. For the National Albion cultivar, a lower AT was observed in S4 than in the other combinations of substrates. The fruits produced by Camarosa plants of National origin showed the lowest AT for all the combinations of substrates used (Table 1).
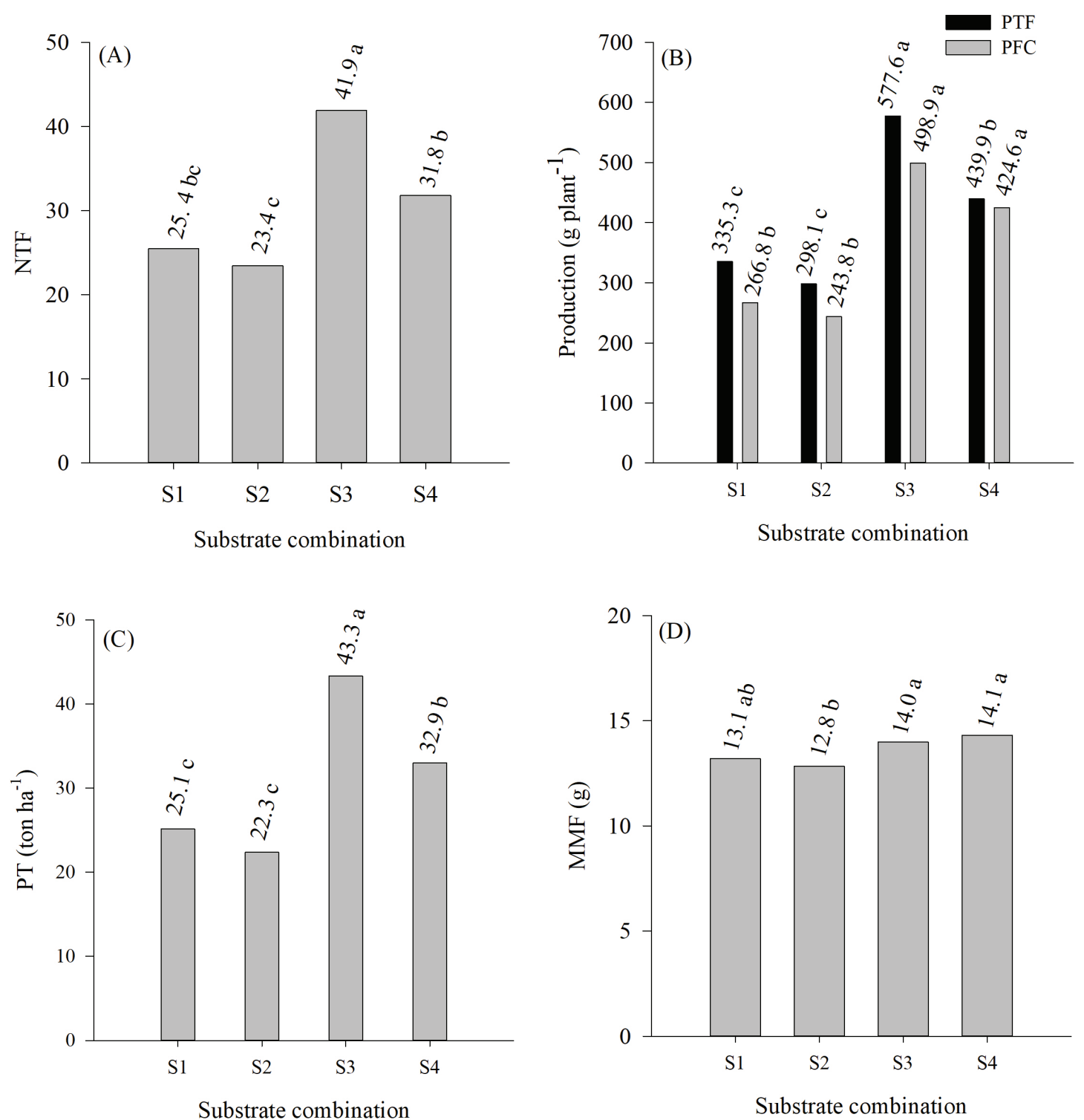

Figure 3: Substrate effect on yield. (A) Total number of fruits (NTF); (B) Production of commercial fruits (PFC) and Total fruit production (PTF); (C) Total Productivity (PT); and (D) Average fruit mass (MMF). Means followed by the same letter do not differ from each other based on a $5 \%$ probability of error. 


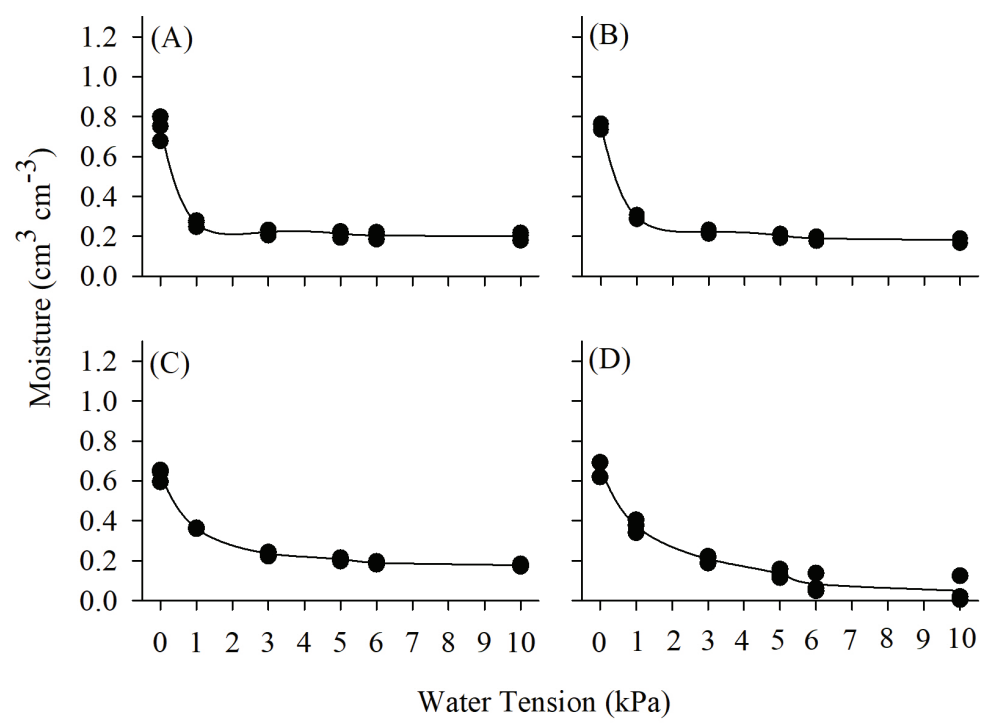

Figure 4: Water retention curve for substrate combinations: (A) S1: crushed sugarcane bagasse (70\%) + organic compost (30\%); (B) S2: crushed sugarcane bagasse (70\%) + Carolina ${ }^{\circledR}$ commercial substrate (30\%); (C) S3: burnt rice husks (70\%) + organic compost (30\%); and (D) S4: burnt rice husks (70\%) + Carolina commercial substrate (30\%)].

Table 1: Total acidity (AT) for Camarosa and Albion strawberry cultivars of both Imported and National origin cultivated in different substrates (S1, S2, S3 and S4).

\begin{tabular}{ccccc}
\hline \multirow{2}{*}{ Substrates } & \multicolumn{2}{c}{ Camarosa } & \multicolumn{2}{c}{ Albion } \\
\cline { 2 - 5 } & National & Imported & National & Imported \\
\hline S1 & $1.07 \mathrm{aB \beta}$ & $1.57 \mathrm{aAa}$ & $1.67 \mathrm{aAa}$ & $1.55 \mathrm{aAa}$ \\
S2 & $1.22 \mathrm{aB \beta}$ & $1.5 \mathrm{aAa}$ & $1.62 \mathrm{aAa}$ & $1.62 \mathrm{aAa}$ \\
S3 & $1.17 \mathrm{aB \beta}$ & $1.45 \mathrm{aAa}$ & $1.65 \mathrm{aAa}$ & $1.42 \mathrm{aAa}$ \\
S4 & $1.12 \mathrm{aAa}$ & $1.17 \mathrm{bA \beta}$ & $1.27 \mathrm{bBa}$ & $1.52 \mathrm{aAa}$ \\
CV (\%) & \multicolumn{4}{c}{12.82} \\
\hline
\end{tabular}

*Lowercase letters compare substrates for each cultivar and each origin, uppercase letters compare each cultivar in different transplant origins, and Greek letters compare the origin of the transplants within cultivars at a $5 \%$ level of probability.

The Albion cultivar presented higher values of SST than did the Camarosa cultivar. For the factor of transplant origin, it was verified that the Imported transplants had higher values than did those of National origin (Figure 5A). The cultivars have different degrees of SST (Cao et al., 2015); in addition, the origin of the cultivars may influence the SST. For example, European cultivars have a lower SST content than do Japanese cultivars (Samykanno; Panga; Marriot, 2013; Yashiro; Tomita; Ezura, 2002). SST content is more dependent on environmental conditions than on genotypes. That is, the variation in SST content can be modified by a system of cultivation as well as by cultural practices such as planting time, soil cover, fertilization and irrigation (Correia et al., 2011; Moshiur Rahman et al., 2014).

For the variable SST/AT, it was verified that Camarosa plants of National origin showed a higher SST/AT ratio than did those of Imported origin $(p<0.05)$. Camarosa of National origin also showed a higher $\mathrm{SST} / \mathrm{AT}$ ratio when compared to Albion of the same origin $(p<0.05)$; as for the Imported origin, there was no significant difference between the cultivars (Figure 5B). The ratio SST/AT depends on the crop and on the harvest season (Krüger et al., 2012; Šamec et al., 2016). According to Samikanno et al. (2013), the fruits of the Albion cultivar had a lower SST/AT ratio with an average of 10. The cultivar Camarosa presented a lower value of SST/AT (7.7) than did the Festival and Ventana cultivars, which suggests a lower quality of this cultivar (Neocleous et al., 2012). These same authors did not find differences according to the type of substrate used.

Soluble sugars are direct products of photosynthesis, and differences in fruit sugar content also indirectly reflect photosynthetic efficiency (Yu et al., 2015). The percentage of citric acid may vary according to the cultivars, as found by Samikanno et al. (2013), who observed higher relative values of AT $(1.0 \%$ citric acid) in the fruits. 

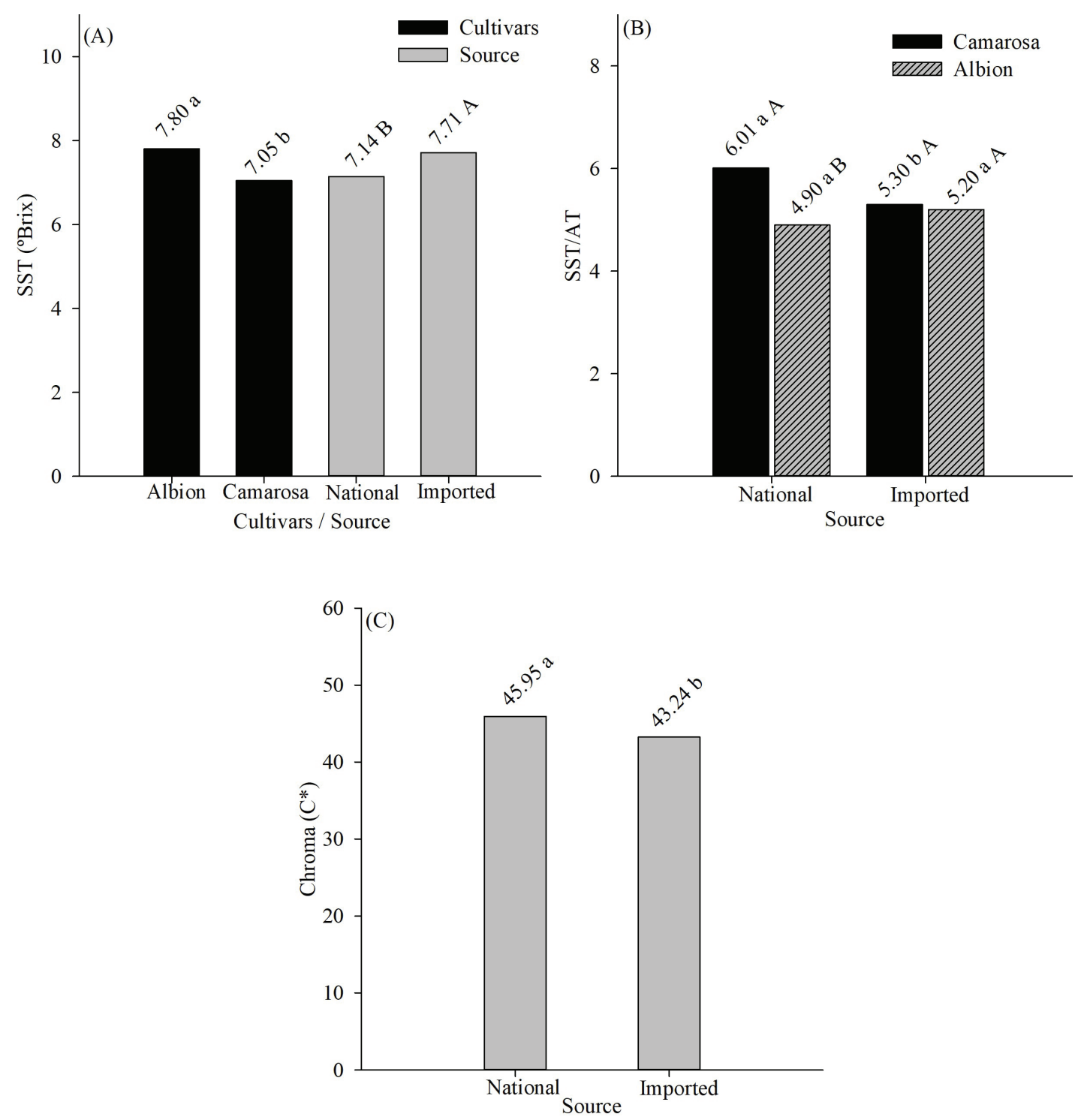

Figure 5: Total soluble solid content (SST) (A), the ratio SST/AT (B) and chroma (C*) (C) of strawberry cultivars of National and Imported origins and cultivated in different combinations of substrates. Lowercase letters compare transplant origins within each cultivar, and uppercase letters compare the different cultivars within each seed source $(p<0.05)$.

Neocleous (2012) observed that the Camarosa cultivar produced more-acidic fruits $(0.92 \%$ citric acid $)$ and Correia et al. (2011) observed that Camarosa had the highest AT values, with a mean of $0.42 \%$ citric acid. It can thus be inferred that differences in the acidity of the fruits are influenced by genotype. With regard to ${ }^{\circ} \mathrm{Brix}$, values may vary between cultivars and cultivation sites; for example, in a conventional cultivation system in Mexico, averages ranged from 8.4 to $9.0^{\circ} \mathrm{Brix}$ (Ornelas-
Paz et al., 2013), and for Albion cultivated in a protected environment in China, Cao et al. (2015) observed values of 7 and $8^{\circ}$ Brix.

The chroma values were significantly higher in transplants of National origin than in those of Imported origin (Figure 5C), which indicates that these fruits presented a more intense red colour (a more attractive colour for the consumer market). The greater the value of $C^{*}$, the redder the fruit is (Šamec et al., 2016). More 
vibrantly red fruit is likely related to larger amounts of anthocyanins (Josuttis et al., 2012), which can be attributed to the higher content of 3-glucoside pelargonidin, an anthocyanin that results in the red colour of strawberries (Krüger et al., 2012).

There is a relationship between temperature and genotype, and the increase in the thermal amplitude between day and night can affect the colour of the fruits (Šamec et al., 2016). In addition, the value of $C^{*}$ can be influenced by the location where the fruits are produced (Cocco et al., 2015). For example, when the cultivar Korona was cultivated in areas farther south relative to the Northern Hemisphere, higher values of $\mathrm{C}^{*}$ were observed compared with those grown farther north, suggesting a positive effect of low temperatures on colour saturation (Krüger et al., 2012). These results contradict what was verified in the present work, in which higher chroma values were observed when the transplants of National origin were cultivated under higher temperatures.

\section{CONCLUSIONS}

The present study has shown that when cultivated in organic compost + burnt rice husks, the cultivar Camarosa of National origin presented the best values of production and quality of strawberry fruits. The physical characteristics of the substrate mixture used should be taken into account. The water holding capacity is crucial to provide a good environment for high fruit production capacity. From the results obtained in this study, it is possible to infer that substrates with ideal physical characteristics can greatly affect the production of strawberry plants and, in some cases, provide regional producers with low-cost alternatives to more conventional substrates and thus increase the net profitability of cultivation systems.

\section{REFERENCES}

ABAD, M. et al. Physical properties of various coconut coir dusts compared to peat. HortScience, 40(7):2138-2144, 2005.

ALVARES, C. A. et al. Köppen's climate classification map for Brazil. Meteorologische Zeitschrift, 22(6):711-728, 2013.

ANTUNES, L. E. C.; DUARTE FILHO, J. Sistema de produção do morango. In: SANTOS, A. M. et al. Sistemas de produção. Pelotas, RS: EMBRAPA CT, 2005. Available in: <http:// sistemasdeproducao.cnptia.embrapa.br>. Access in: December, 23, 2015.

BRADFORD, E.; HANCOCK, J. F.; WARNER, R. M. Interactions of temperature and photoperiod determine expression of repeat flowering in strawberry. Journal of the American Society for Horticultural Science, 135(2):102-107, 2010.

CAO, F. et al. Soluble solids content is positively correlated with phosphorus content in ripening strawberry fruits. Scientia Horticulturae, 195(12):183-187, 2015.

COCCO, C. et al. Effects of site and genotype on strawberry fruits quality traits and bioactive compounds. Journal of Berry Research, 5(3):145-155, 2015.

CORREIA, P. J. et al. Relationships between strawberry fruit quality attributes and crop load. Scientia Horticulturae, 130(2):398-403, 2011.

DARNELL, R. L. et al. The physiology of flowering in strawberry. Horticultural Reviews, 28:325-350, 2003.

DIEL, M. I. et al. Efficiency of water use for strawberries cultivated in different semi-hydroponic substrates. Australian Journal of Basic and Applied Sciences, 10(8):31-37, 2016.

DIEL, M. I. et al. Phyllochron and phenology of strawberry cultivars from different origins cultivated in organic substracts. Scientia Horticulturae, 220:226-232, 2017.

DURNER, E. F. et al. Photoperiod and temperature effects on flower and runner development in day-neutral, Junebearing, and everbearing strawberries. Journal of the American Society for Horticultural Science, 109:396400, 1984.

FAOSTAT. Food and Agriculture Organization of the United Nations Statistics Division. Available in: <http://faostat3. fao.org>. Access in: May, 31, 2016.

GODOI, R. S. et al. Produção e qualidade do morangueiro em sistemas fechados de cultivo sem solo com emprego de substratos. Ciência Rural, 39(4):1039-1044, 2009.

GONÇALVES, M. A. et al. Produção de morango fora do solo. Pelotas: Embrapa Clima Temperado, 32p. 2016.

HEIDE, O. M.; STAVANG, J. A.; SONSTEBY, A. Physiology and genetics of flowering in cultivated and wild strawberries - A review. The Journal of Horticultural Science and Biotechnology, 88(1):1-18, 2013.

JOSUTTIS, M. et al. A comparison of bioactive compounds of strawberry fruit from Europe affected by genotype and latitude. Journal of Berry Research, 2(2):73-95, 2012.

KRÜGER, E. et al. Influence of growing conditions at different latitudes of Europe on strawberry growth performance, yield and quality. Journal of Berry Research, 2(3):143157, 2012. 
LI, H. et al. Strawberry plant fruiting efficiency and its correlation with solar irradiance, temperature and reflectance water index variation. Environmental and Experimental Botany 68(2):165-174, 2010.

MARTÍNEZ-FERRI, E. et al. Water relations, growth and physiological response of seven strawberry cultivars (Fragaria $\times$ ananassa Duch.) to different water availability. Agricultural Water Management, 164(1):73-82, 2016.

MASSA, G. D. et al. Temperature affects long-term productivity and quality attributes of day-neutral strawberry for a space life-support system. Life Sciences in Space Research, 5:39-46, 2015.

MEDEIROS, C. A. B.; STRASSBURGER, A. S.; ANTUNES, L. E. C. Avaliação de substratos constituídos de casca de arroz no cultivo sem solo do morangueiro. Horticultura Brasileira, 26(2):S4827-S4831, 2008.

MOSHIUR RAHMAN, M. et al. Effect of planting time and genotypes growth: Yield and quality of strawberry (Fragaria × ananassa Duch). Scientia Horticulturae, 167:56-62, 2014.

MORRISON, B.; HERRINGTON, M. Strawberry breeding in Australia. Acta Horticulturae, 567:125-128, 2002.

NEOCLEOUS, D. Effects of cultivars and coco-substrates on soilless strawberry production in Cyprus. Journal of Berry Research, 2(4):207-213, 2012.

OLIVEIRA, R. P.; SCIVITTARO, W. B. Produção de frutos de morango em função de diferentes períodos de vernalização das mudas. Horticultura Brasileira, 27(1):91-95, 2009.

OLIVEIRA, R. P.; NINO, A. F. P.; SCIVITTARO, W. B. Mudas certificadas de morangueiro: Maior produção e melhor qualidade de fruta. A Lavoura, 108(655):35-38, 2005.

ORNELAS-PAZ, J. J. et al. Physical attributes and chemical composition of organic strawberry fruit (Fragaria $\mathrm{x}$ ananassa Duch, Cv. Albion) at six stages of ripening. Food Chemistry, 138(1):372-381, 2013.

PÁDUA, J. G. et al. Desempenho agronômico e comportamento de cultivares de morangueiro quanto à mancha-depestalotiopsis e às podridões dos frutos. Revista Agrogeoambiental, 7(1):65-74, 2015.

RADIN, B. et al. Desempenho de quatro cultivares de morangueiro em duas regiões ecoclimáticas do Rio Grande do Sul. Horticultura Brasileira, 29(3):287-291, 2011.

ROSA, H. et al. Crescimento vegetativo e produtivo de duas cultivares de morango sob épocas de plantio em ambiente subtropical. Revista Ciência Agronômica, 44(3):604-613, 2013.
ŠAMEC, D. et al. Assessment of the differences in the physical, chemical and phytochemical properties of four strawberry cultivars using principal component analysis. Food Chemistry, 194:828-834, 2016.

SAMYKANNO, A. K.; PANGA, E.; MARRIOT, P. J. Genotypic and environmental effects on flavor attributes of 'Albion' and 'Juliette' strawberry fruits. Scientia Horticulturae, 164:633642, 2013.

SAS institute Inc. SAS/STAT 9.22 User's Guide. Cary, NC: SAS Institute Inc. 2010.

SILVA, M. S.; DIAS, M. S. C.; PACHECO, D. D. Productivity and quality of strawberry cultivars in the north of Minas Gerais. Horticultura Brasileira, 33(2):251-256, 2015.

SONSTEBY, A.; OPSTAD, H.; HEIDE O. M. Environmental manipulation for establishing high yield potential of strawberry forcing plants. Scientia Horticulturae, 157:6573, 2013.

TULLIO, J. A. et al. Cultivo de beterraba em ambientes protegido e natural na época de verão. Revista Brasileira de Engenharia Agrícola e Ambiental, 17(10):1074-1079, 2013.

VERDIAL, M. F. et al. Fisiologia de mudas de morangueiro produzidas em sistema convencional e em vasos suspensos. Revista Brasileira de Fruticultura, 31(2):524-531, 2009.

WANG, D. et al. Characteristics of growing media mixes and application for open-field production of strawberry (Fragaria ananassa). Scientia Horticulturae, 198:294-303, 2016.

WREGE, M. S. et al. Zoneamento agroclimático para produção de mudas de morangueiro no Rio Grande do Sul. Documentos, 187. Pelotas: Embrapa Clima Temperado, 27p. 2007.

$X U$, F. et al. Effect of blue light treatment on fruit quality, antioxidant enzymes and radical-scavenging activity in strawberry fruit. Scientia Horticulturae, 175:181-186, 2014.

YASHIRO, K.; TOMITA, K.; EZURA, H. Is it possible to breed strawberry cultivars, which confer firmness and sweetness? Acta Horticulturae, 567:223-226, 2002.

YU, J. et al. Analysis and evaluation of strawberry growth, photosynthetic characteristics, biomass yield and quality in an artificial closed ecosystem. Scientia Horticulturae, 195:188-194, 2015.

ZHANG, Y. et al. Isolation and identification of strawberry phenolics with antioxidant and human cancer cell antiproliferative properties. Journal of Agricultural and Food Chemistry, 56(3):670-675, 2008. 